\title{
The Biochemical Properties of Manganese in Plants
}

\author{
Sidsel Birkelund Schmidt * ${ }^{+}$and Søren Husted \\ Department of Plant and Environmental Sciences, Faculty of Science, University of Copenhagen, \\ 1871 Frederiksberg C., Denmark; shu@plen.ku.dk \\ * Correspondence: sisc@plen.ku.dk
}

Received: 28 August 2019; Accepted: 24 September 2019; Published: 27 September 2019

check for updates

\begin{abstract}
Manganese (Mn) is an essential micronutrient with many functional roles in plant metabolism. Manganese acts as an activator and co-factor of hundreds of metalloenzymes in plants. Because of its ability to readily change oxidation state in biological systems, Mn plays and important role in a broad range of enzyme-catalyzed reactions, including redox reactions, phosphorylation, decarboxylation, and hydrolysis. Manganese(II) is the prevalent oxidation state of $\mathrm{Mn}$ in plants and exhibits fast ligand exchange kinetics, which means that Mn can often be substituted by other metal ions, such as $\mathrm{Mg}(\mathrm{II})$, which has similar ion characteristics and requirements to the ligand environment of the metal binding sites. Knowledge of the molecular mechanisms catalyzed by Mn and regulation of Mn insertion into the active site of Mn-dependent enzymes, in the presence of other metals, is gradually evolving. This review presents an overview of the chemistry and biochemistry of Mn in plants, including an updated list of known Mn-dependent enzymes, together with enzymes where Mn has been shown to exchange with other metal ions. Furthermore, the current knowledge of the structure and functional role of the three most well characterized Mn-containing metalloenzymes in plants; the oxygen evolving complex of photosystem II, Mn superoxide dismutase, and oxalate oxidase is summarized.
\end{abstract}

Keywords: Manganese; enzyme; metalloenzyme; database; catalysis; photosystem II; Mn cluster; superoxide dismutase; oxalate oxidase

\section{Introduction-Manganese as an Essential Plant Nutrient}

Manganese (Mn) is an essential micronutrient in most organisms. More than 200 years ago, the presence of $\mathrm{Mn}$ in leaf tissue of plants was experimentally documented for the first time in the ash of several vegetable species [1]. During the following 100 years, Mn was found in most important crops, but it was not until the early 1900s that Mn was documented as being required for plant growth and development [2,3]. The probable role of Mn in oxygenic photosynthesis was demonstrated for the first time by Pirson and co-workers, who recognized that plants and algae are unable to release $\mathrm{O}_{2}$ in the absence of $\mathrm{Mn}$ in their growth medium [4,5]. Later, the redox-dependent function of oxygen evolution was discovered by Kok et al. [6]. However, the biological role of Mn in catalyzing oxygen evolution remained unclear until Spector and Winget [7] managed to isolate a catalytically active Mn-containing protein complex from spinach, providing evidence that $\mathrm{Mn}$ is an integral and essential metal cofactor in the oxygen evolving complex (OEC) of higher plants.

Manganese biogeochemistry in soils is complex, because Mn exists in three oxidation states, Mn(II), $\mathrm{Mn}(\mathrm{III})$, and $\mathrm{Mn}(\mathrm{IV})$ in the soil solution. Only the divalent form $\left(\mathrm{Mn}^{2+}\right)$ is available for plant uptake, as $\mathrm{Mn}(\mathrm{III})$ is unstable and $\mathrm{Mn}(\mathrm{IV})$ forms highly insoluble oxides and precipitates. Although Mn is abundant in most soils, particular soil $\mathrm{pH}$ and redox conditions greatly influence the concentration of $\mathrm{Mn}^{2+}$ in soils, with a high $\mathrm{pH}$ reducing its availability through $\mathrm{MnO}_{2}$ formation, whereas reducing $\mathrm{O}_{2}$ in the soil air by soil compaction or flooding, increases the $\mathrm{Mn}^{2+}$ concentration [8]. In the field, 
Mn deficiency therefore commonly appears patchy due to an uneven distribution of the soil conditions favoring Mn oxidation or reduction. Manganese deficiency is a widespread problem, particularly in dry, calcareous, and sandy soils worldwide [9-15]. Symptoms of the deficiency develop as interveinal chlorosis in newly emerged leaves, while prolonged deficiency causes leaf necrosis, which appears as brown spots between veins in older leaves [8]. In problematic regions, Mn deficiency significantly reduces crop yields, and can even cause complete crop loss in severe winters [10].

Manganese is a metal co-factor for approximately $6 \%$ of all known metalloenzymes [16]. A relatively large number of enzymes are activated by $\mathrm{Mn}^{2+}$, but only a few metalloenzymes are currently known to have an absolute and non-replaceable requirement for $\mathrm{Mn}$ to become catalytically active [17]. In plants, the most well studied and described Mn-dependent enzymes include the Mn superoxide dismutase (Mn-SOD), oxalate oxidase (OxOx), and the Mn cluster in photosystem II (PSII), catalyzing the split of water, which provides the necessary electrons for driving photosynthesis. Thus, a lack of available Mn has negative impacts on plant growth and development by precluding the functional roles associated with these key-enzymes, such as scavenging of reactive oxygen species, seed germination, and fungal protection as well as photosynthesis in plants.

\section{The Biological Chemistry of Manganese in Plants}

Manganese is a first-row transition element found in nature as the stable isotope ${ }^{55} \mathrm{Mn}$. Manganese exists in the oxidation states $+2,+3,+4,+6$, and +7 , but the $+2(\mathrm{Mn}(\mathrm{II})$ ) oxidation state is most prevalent in biological systems. However, extensive redox cycling between the oxidation states $+2,+3$, and +4 occurs in the rhizosphere, in plant Mn metalloenzymes, such as Mn-SOD [18], OxOx (Whittaker et al., 2007), and in the OEC of photosystem II (PS II) [6]. The most common coordination geometries of Mn in proteins is octahedral (Oh, coordination number, $n=6)$, square pyramidal and trigonal bipyramidal (TBp, $n=5$ ) and tetrahedral (Th, $n=4$ ) (Figure 1). Manganese ions exhibit fast ligand exchange kinetics, which means they can easily be replaced by other divalent metal ions, including $\mathrm{Mg}, \mathrm{Ca}, \mathrm{Fe}, \mathrm{Co}, \mathrm{Cu}$, and $\mathrm{Zn}$. The selection of metal centers in metalloenzymes has been influenced by the availability of metals through geological time, as the readiness of specific metals appears to be the driving force behind most of enzyme evolution [19]. Before the emergence of oxygen-evolving photosynthesis, the earth existed in a strong reductive environment, with the ancient oceans having large sulfur contents that affected metal solubility with Fe and Mn dissolving and, $\mathrm{Cu}$ and $\mathrm{Zn}$ precipitating under these conditions. In contrast, under current oxygenic conditions the bioavailability of these metals are completely reversed, with the affinity for divalent metal ions to the exchange of complexed water $\left(\mathrm{H}_{2} \mathrm{O}\right)$ for any other ligand within a metal complex given by the Irving-Williams series [20]: $\mathrm{Mg}^{2+}$ $<\mathrm{Mn}^{2+}<\mathrm{Fe}^{2+}<\mathrm{Co}^{2+}<\mathrm{Ni}^{2+}<\mathrm{Cu}^{2+}>\mathrm{Zn}^{2+}$. This states that $\mathrm{Mn}^{2+}$ is a relative weak binding metal in proteins.

Metal ions are characterized as Lewis acids because they can accept a pair of electrons (a lone pair) from a donor molecule and form a coordinate covalent bond. Ligands are defined as Lewis bases as they donate lone pairs to the metal ion when a complex is formed. The strength of a Lewis acid is largely determined by the charge density, i.e., the higher the valence and the smaller the ion radius, the stronger the acidity of a given metal ion. Ions with high charge density in combination with a low polarizability, which is a measure of how easily an electron cloud is distorted by an electric field, are designated as hard acids. Hard acids tend to form strong complexes with hard bases, whereas soft acids form strong bonds with soft bases [21]. This trend is named the "HSAB" rule: "the hard-soft acid-base rule" and is a very convenient measure of the affinity between metal ions and ligands (Table 1) [21]. 
(a)

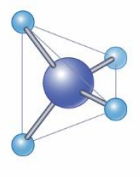

(Td)

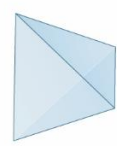

(b)

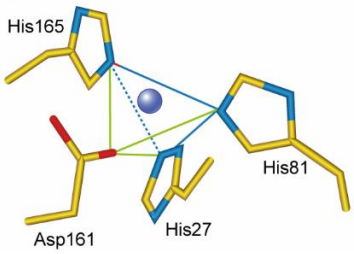

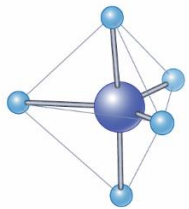

(TBp)
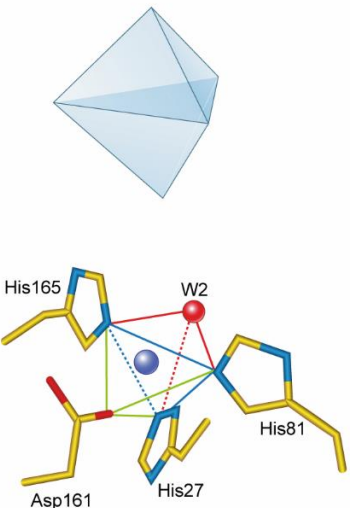
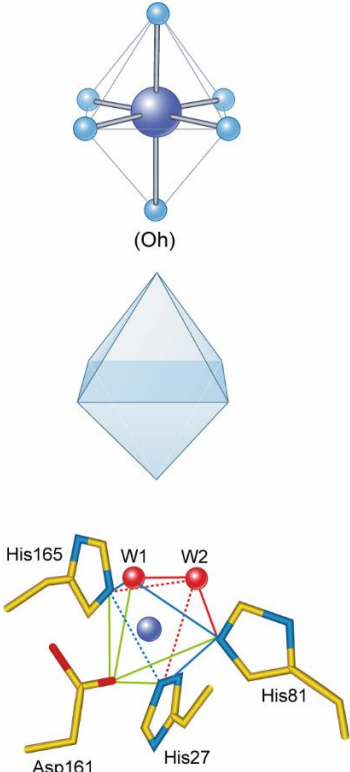

Figure 1. (a) The three dominating coordination geometries and coordination numbers observed in Mn (purple sphere) containing metalloproteins are tetrahedral $(\mathrm{Td}, n=4)$; trigonal bipyramidal (TBp, $n=5)$ and octahedral (Oh, $n=6)$. (b) The active site of Mn-SOD in the presence of Mn (purple sphere), with and without water molecules (W1 and W2, red spheres) in the coordinating sphere. Three His residues (His 165, 27, and 81), one Asp (161) coordinates Mn, and the involvement of 0, 1, or 2 water molecules determines the geometry of the Mn complex at the active site. Zero water produces Td, binding of W1 yields TBp, and binding of W1 and W2 produces the Oh geometry. It has been speculated that the geometry of the active sites changes during scavenging of reactive oxygen species [22].

Table 1. Chemical properties of selected divalent metal ions. The second ionization potential (eV) has proven to be a useful proxy for the polarizability of biologically relevant metal ions. The ionic radii are adapted from Irving and Williams [23] and all other values are adapted from Andreini et al. [24]. According to the hard and soft acids and bases (HSAB) classification, the metal ions (Lewis acids) are divided into hard $(\mathrm{H})$, borderline $(\mathrm{B})$, or hard-borderline $(\mathrm{HB})$ types. The most common coordination geometries are abbreviated as follows: $\mathrm{T}_{\mathrm{d}}$, tetrahedral; $\mathrm{O}_{\mathrm{h}}$, octahedral; $\mathrm{D}_{3 \mathrm{~h}}$, trigonal bipyramidal; $\mathrm{D}_{4 h}$, square planar; $\mathrm{C}_{4 \mathrm{v}}$, square pyramidal; $\mathrm{IR}$, irregular.

\begin{tabular}{|c|c|c|c|c|c|c|c|c|}
\hline & $\mathrm{Ca}$ & $\mathrm{Mg}$ & Mn & $\mathrm{Fe}$ & Co & $\mathrm{Ni}$ & $\mathrm{Cu}$ & $\mathrm{Zn}$ \\
\hline $\begin{array}{l}\text { Ionic radius }(\AA) \text { of the } \\
\text { free metal ion }\end{array}$ & 0.99 & 0.66 & 0.78 & 0.76 & 0.74 & 0.73 & 0.72 & 0.72 \\
\hline $\begin{array}{l}\text { Second ionization } \\
\text { potential }(\mathrm{eV}) \text { : }\end{array}$ & 11.87 & 15.04 & 15.64 & 16.18 & 17.06 & 18.15 & 20.29 & 17.96 \\
\hline HSAB classification: & $\mathrm{H}$ & $\mathrm{H}$ & $\mathrm{HB}$ & B & B & B & B & B \\
\hline Ligands: & $\mathrm{O}$ & $\mathrm{O}$ & $\mathrm{N}, \mathrm{O}, \mathrm{S}$ & $\mathrm{N}, \mathrm{S}, \mathrm{O}$ & $\mathrm{N}, \mathrm{O}, \mathrm{S}$ & $\mathrm{S}, \mathrm{N}$ & $\mathrm{S}, \mathrm{N}$ & $\mathrm{N}, \mathrm{S}, \mathrm{O}$ \\
\hline Coordination numbers: & $6,7,8$ & 6 & $4,5,6$ & $4,5,6$ & $4,5,6$ & $4,5,6$ & $4,5,6$ & $4,5,6$ \\
\hline Dominating geometries: & $\mathrm{O}_{\mathrm{h}}, \mathrm{IR}, \mathrm{IR}$ & $\mathrm{O}_{\mathrm{h}}$ & $\mathrm{T}_{\mathrm{d}}, \mathrm{D}_{3 \mathrm{~h}}, \mathrm{O}_{\mathrm{h}}$ & $\begin{array}{c}\mathrm{T}_{\mathrm{d}} / \mathrm{D}_{4 \mathrm{~h}} \\
\mathrm{C}_{4 \mathrm{v}} / \mathrm{D}_{3 \mathrm{H}}, \mathrm{O}_{\mathrm{h}}\end{array}$ & $\begin{array}{c}\mathrm{T}_{\mathrm{d}}, \mathrm{C}_{4 \mathrm{v}} / \mathrm{D}_{3 \mathrm{~h}} \\
\mathrm{O}_{\mathrm{h}}\end{array}$ & $\mathrm{O}_{\mathrm{h}}, \mathrm{T}_{\mathrm{d}}, \mathrm{D}_{4 \mathrm{~h}}$ & $\begin{array}{c}\mathrm{T}_{\mathrm{d}} / \mathrm{D}_{4 \mathrm{~h}} \\
\mathrm{C}_{4 \mathrm{v}} / \mathrm{D}_{3 \mathrm{~h}}, \mathrm{O}_{\mathrm{h}}\end{array}$ & $\begin{array}{c}\mathrm{T}_{\mathrm{d}}, \mathrm{C}_{4 \mathrm{v}} / \mathrm{D}_{3 \mathrm{~h}}, \\
\mathrm{O}_{\mathrm{h}}\end{array}$ \\
\hline
\end{tabular}

Among the biological relevant transition elements, $\mathrm{Mn}^{2+}$ is considered a "hard" to "borderline" ion, i.e., an ion with a large charge density and a low polarizability. As a consequence, Mn prefers coordination with hard ligands such as the negatively charged oxygen atoms in the carboxylate groups of aspartate (Asp) and glutamate (Glu), as well as the polar oxygen atoms within carbonyl groups of asparagine (Asn), glutamine (Gln) and water molecules $\left(\mathrm{H}_{2} \mathrm{O}\right)$. The borderline aromatic $\mathrm{N}$ containing imidazole ring of histidine (His) is another important ligand for $\mathrm{Mn}^{2+}$. In contrast, the sulfur (S) containing amino acids cysteine and methionine are soft ligands and are consequently less likely to coordinate with $\mathrm{Mn}^{2+}$. Up until now there is no identification of Mn metalloenzymes which contain a 
Mn-S coordination sphere [25], but several synthetic Mn complexes with both oxygen $(\mathrm{O})$, nitrogen $(\mathrm{N})$, and $\mathrm{S}$ ligands have been characterized [18].

\section{Manganese in Metalloenzymes}

Manganese has two major functions in enzymes: (i) as a Lewis acid, for which the properties of $\mathrm{Mn}$ are similar to $\mathrm{Mg}$, Co and $\mathrm{Zn}$ and (ii) as an oxidation catalyst, for which it can be compared with properties similar to that of other redox active metal ions, such as $\mathrm{Fe}$ and $\mathrm{Cu}$ (Table 1). In Arabidopsis, 101 identified enzymes contain $\mathrm{Mn}$ in the active site, but only one third of them appear to have an absolute requirement for Mn (The UniProt Knowledgebase (http://www.uniprot.org), accessed 2 July 2019) (Figure 2). For the majority of Mn containing metalloenzymes, Mn is interchangeable with other divalent metal cation. Manganese (II) has a radius of approximately $0.78 \AA$, somewhat larger than that of magnesium $(\mathrm{Mg}, 0.66 \AA)$, but smaller than that of calcium $(\mathrm{Ca}, 0.99 \AA)$, and almost the same as that of zinc $(\mathrm{Zn}, 0.72 \AA)$, copper $(\mathrm{Cu}, 0.72 \AA)$, and cobalt $(\mathrm{Co}, 0.74 \AA)$. Considering the similar sizes, charges and HSAB classification of Mn and the other transition metals listed in Table 1 , they might be expected to substitute for each other in proteins and in biochemical reactions. However, this is rarely the case, as the biochemical behavior of $\mathrm{Mn}^{2+}$ resembles that of $\mathrm{Mg}^{2+}$ more than e.g., $\mathrm{Zn}^{2+}$ and the remaining transition elements listed (Table 1).

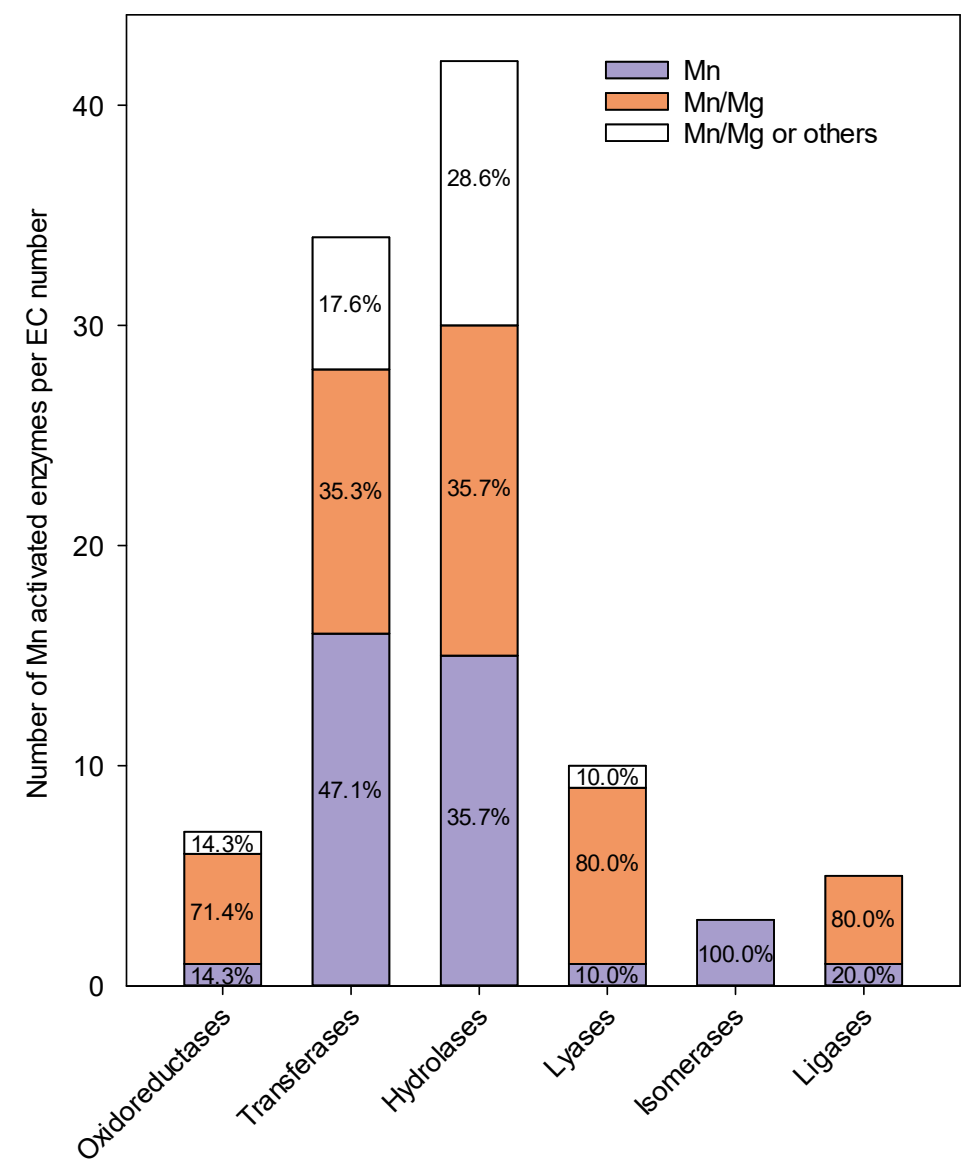

EC class

Figure 2. Distribution of Mn activated enzymes across the six Enzyme Commission (EC) classes together with the relative frequencies (\%) of the coordinated metal ion for each EC class. A total of 101distinct Mn activated enzymes is described in the UniProt Knowledgebase for Arabidopsis thaliana, when filtered by reviewed records, accessible cofactor information, and protein name. Of these enzymes, 37 exclusively contain $\mathrm{Mn}$ as a cofactor, 44 enzymes are activated by either $\mathrm{Mn}$ or $\mathrm{Mg}$, while 20 enzymes are reported to coordinate with $\mathrm{Mn}, \mathrm{Mg}$, or other divalent metals ( $\mathrm{Ca}, \mathrm{Zn}, \mathrm{Fe}, \mathrm{Co}, \mathrm{Ni}, \mathrm{Cu}$ ). 
Manganese and $\mathrm{Mg}$ ions share a number of chemical and biochemical characteristics: The ionic radii of $\mathrm{Mg}^{2+}(0.66 \AA)$ and $\mathrm{Mn}^{2+}(0.67 \AA)$ are almost identical in the low spin state (bound state), where the metal ions have as many electrons paired as possible. The orbital composition of Mn is very different from that of $\mathrm{Mg}$ because it includes $d$ orbitals. A shift from a low spin state to a high spin state (free ions, Table 1), does not influence the ionic radius of $\mathrm{Mg}^{2+}$, which remains at $0.66 \AA$, whereas that of $\mathrm{Mn}^{2+}$ substantially increases to $0.78 \AA$ [26]. These metals, characterized as hard (Mg) to hard-borderline $(\mathrm{Mn})$ metal ions, have the same ability to form divalent cations, and may form complexes of the same geometry using oxygen ligands (Table 1). Thus, generally few differences exist between $\mathrm{Mg}$ and $\mathrm{Mn}$ coordination spheres responsible for the cation specificity. Khrustalev et al. [27] investigated several hundred $\mathrm{Mn}$ and $\mathrm{Mg}$ metalloproteins and found that $\mathrm{Mg}$ and $\mathrm{Mn}$ are typically bound to oxygen in the carboxylate groups of Asp and Glu. Histidine (His) residues appear underrepresented in Asp and Glu rich pockets binding $\mathrm{Mg}^{2+}$, while His groups are overrepresented in Asp and Glu pockets binding $\mathrm{Mn}^{2+}$. When replacing $\mathrm{Mg}$ in the active site with divalent $\mathrm{Mn}$, the catalytic activity of the enzyme is often maintained [28]. In contrast, the enzyme functionality is often lost when Mg exchanged with $\mathrm{Mn}$ in a Mn-dependent enzyme. The exact reason for this striking difference between $\mathrm{Mg}$ and Mn specificity remains to be resolved [29]. Due to the similarities of the coordination spheres for Mn and $\mathrm{Mg}$ and due to their low rank in the Irving-Williams series, the potential risk of mismetallation in $\mathrm{Mn}$ and $\mathrm{Mg}$ metalloproteins is high. In the plant cell, the risk of mismetallation is reduced by cellular compartmentation and a tight homeostatic regulation. In leaf tissue, most $\mathrm{Mn}$ and $\mathrm{Mg}$ is sequestered in the vacuoles, and allocation to the chloroplasts, golgi and mitochondria, where both metals serve key functions, is tightly regulated at the $\mathrm{Mn}$ and $\mathrm{Mg}$ transporter level [30,31].

Across the 6 enzyme classes, $44 \%$ of all Mn containing metalloenzymes can bind $\mathrm{Mg}$ with different $\mathrm{Mn} / \mathrm{Mg}$ stoichiometries (Figure 2). It is important to note that information about metal binding in metalloproteins must be viewed with caution, as evidence is most often based on in vitro experiments, where the metal might be lost or exchanged during the extraction and purification process. It is therefore likely that $\mathrm{Mg}$ (an essential macronutrient) dependent enzymes are overrepresented in Figure 2, as $\mathrm{Mg}$ is typically found in 100-fold excess relative to Mn (being an essential micronutrient) in homogenized plant tissue and in specific cell compartments, including the cytosol and chloroplasts [32,33]. In fact, only very few of the currently known Mn-bound enzymes have been experimentally validated.

Substitution of $\mathrm{Mg}$ with $\mathrm{Mn}$ typically changes the catalytic rate of the enzyme and in many cases it also changes the functional role of the enzyme [34]. Rubisco (Ribulose-1,5-bisphosphate carboxylase/oxygenase) illustrates well how differential binding of $\mathrm{Mg}$ and $\mathrm{Mn}$ changes the catalytic rate and the substrate preference of a protein ("one protein, two enzymes"). Rubisco is the most abundant protein in plants and catalyzes the carboxylation reaction by fixing atmospheric $\mathrm{CO}_{2}$ in the dark reactions of photosynthesis together with the oxygenation reaction fixing $\mathrm{O}_{2}$ during photorespiration. When Rubisco binds to $\mathrm{Mg}^{2+}$, carboxylation is favored and proceeds 4 to 11 times faster than oxygenation, but when Rubisco binds to $\mathrm{Mn}^{2+}$ carboxylation and oxygenation occur at similar rates [35]. When $\mathrm{Mn}$ is bound to Rubisco it participates in the catalytic process of ribulosebiphosphate (RuBP) oxygenation and becomes reduced with every oxygenation event [34]. However, preference is clearly given to binding of $\mathrm{Mg}$ as the oxygenating capacity of Mn-activated Rubisco is so large that photosynthesis supported by this catalyst would be incapable of sustaining a positive carbon balance in the Earth atmosphere. Kinetic studies have revealed that if Mn was the only metal ion to coordinate with Rubisco then the $\mathrm{CO}_{2}$ compensation point in the mesophyll would need to rise 30-fold ( $>1500 \mathrm{ppmv}$ ) to support photosynthesis. Thus, preference of $\mathrm{Mg}$ binding to Rubisco is therefore a prerequisite for autotropic life on the planet [34], despite this the regulation of metal insertion (Mg vs. $\mathrm{Mn})$ is not fully understood.

\section{Metallation of Manganese Containing Metalloenzymes}

Manganese transporters are essential for uptake, distribution, and storage in the cell, with several different transporter families documented to be implicated in Mn transport in plants [36]. However, 
the molecular mechanism used by cells to avoid mis-metallation of enzymes in the presence of competitive metals remains to be fully resolved. One way to ensure that the correct metal is inserted into the active site of a metalloenzyme is to exploit delivery proteins, also known as chaperones. Metallochaperones play an important role in delivering metal ions to apo-proteins by ensuring correct insertion into the active site of the protein in the multi-ionic environment of the cell, where competing ions may exist in much larger concentrations and with greater affinities towards potential ligands.

The current knowledge of Mn chaperones is mostly obtained from studies in cyanobacteria, and little is known about $\mathrm{Mn}$ chaperones in higher plants. Synechocystis PratA (for processing-associated tetratricopeptide (TPR) protein) functions as an assembly factor required for efficient delivery of $\mathrm{Mn}^{2+}$ to the reaction core of PSII in vivo, during the early steps of thylakoid biogenesis [37]. PratA specifically binds Mn and is assumed to preload the PSII core D1 protein with $\mathrm{Mn}^{2+}$ in the early stages of PSII assembly. In PratA deletion mutants, the $\mathrm{Mn}^{2+}$ loading is reduced by almost 9-fold relative to the wildtype. The Mn binding constant for PratA is much smaller than that observed for other metalloenzymes in which Mn is bound specifically and irreversibly (e.g., Mn-SOD) [38]. This underlines the more transient binding of Mn in PratA allowing it to act as a metallochaperone [37].

In land plants it is speculated that the extrinsic protein PsbP plays a role similar to PratA, by acting as a chaperone for insertion of Mn into the PSII reaction core, where it subsequently, stabilizes and shields the Mn cluster of PSII in association with PsbO and PsbQ, [39,40]. High-resolution crystal structures of PsbP purified from spinach and Zea mays have revealed that two Mn ions are bound within the protein [41]. The first Mn ion (Mn1) is bound in a positively charged pocket coordinated by $\mathrm{Cl}^{-}$and His and Asp groups, and the second Mn (Mn2) in a negatively charged pocket coordinated by Asp and water. Based on protein structural analysis it was proposed that Mn1 represents a high affinity binding site, whereas Mn2 is bound with low affinity. The Mn2 coordination site is believed to be responsible for the proposed chaperone action, as $\mathrm{Mn}$ is more loosely bound and thereby able to donate Mn ions to the reaction core of PSII [41]. As supporting evidence, a marked conformational change of PsbP is observed when Mn2 is lost; leading Ido et al. [42] to speculate that the functional interaction of PsbP with PSII is controlled in a pH-dependent manner.

There are only few cases where Mn-dependent metalloenzymes are known to effectively use metal ions other than $\mathrm{Mn}$ to catalyze a reaction [43]. An example is $\mathrm{Fe} / \mathrm{Mn}$ substitution in cambialistic SODs, which are able to retain a similar activity with either Fe or Mn in the active site [44] (for more details, see section 'Mn-dependent superoxide dismutase'). However, for the majority of enzymes, Mn substitution with Fe or any other metal ion is lethal to the enzymatic activity. In addition to chaperones, compartmentalization is another strategy for correct metallation by keeping competitive metals out of the wrong nascent proteins. Tottey et al. [45] demonstrated how the most abundant $\mathrm{Cu}$ protein, $\mathrm{Cu}$-cupin $\mathrm{A}$ (CucA), and the most abundant Mn protein, Mn-cupin A (MncA), from the periplasm of cyanobacterium both bind their respective metal via identical ligands in a cupin fold. Notably, the cupin prefers $\mathrm{Cu}$ to $\mathrm{Mn}$ in vitro consistent with the Irving-Williams series. Even so, Mn manages to coordinate with cupin in a multi-ionic environment when present in a $10^{4}$-fold excess relative to $\mathrm{Cu}$. When $\mathrm{Mn}$ was bound to the cupin site it possessed high thermodynamic stability and no ligand exchange with $\mathrm{Cu}^{2+}$ or $\mathrm{Zn}^{2+}$ was observed. This finding indicates that the concentration of $\mathrm{Mn}$ in the cytoplasm, where coordination and folding happens, is able to override the affinity of the coordinating sphere of the protein. MncA and CucA have Tat (twin-arginine translocation pathway) and Sec (secretion pathway) signal peptides, respectively, revealing different import pathways of the two proteins into the periplasm. The Tat pathway allows import of folded metallated proteins and thus enables MncA to fold in the cytoplasm where most $\mathrm{Cu}$ and $\mathrm{Zn}$ ions are tightly bound in complexes and free activity of these ions are extremely low, whereas $\mathrm{Mn}^{2+}$ is found in $\mu \mathrm{M}$ concentrations. In contrast, $\mathrm{Cu}$ outcompetes $\mathrm{Mn}$ in the periplasm leading to a preferential CucA folding, revealing a compartmentalization strategy, whereby the cellular compartment in which the protein folds overrides its binding preference in order to control the metal cofactor incorporation. 


\section{Manganese at the Active Site of Water Oxidation in Photosystem II}

The most well studied Mn-containing enzyme is the Mn-cluster, also known as OEC, which is situated and surrounded by a protein matrix in photosystem II. PSII performs a series of electron transfer reactions using solar energy. The light-induced water oxidation requires four electrons and four protons to be stripped from two water molecules. This necessitates four sequential oxidation events, which are catalyzed by the Mn-cluster of the OEC that cycles through different redox states, known as $\mathrm{S}_{i}$ states $(i=0-4)$ (Figure 3a). The unique redox chemistry of Mn (i.e., Mn can carry five charges from $\mathrm{Mn}(\mathrm{II})$ to $\mathrm{Mn}(\mathrm{VII}))$ makes it an ideal element for building the OEC, in which accumulation of four charges is needed to oxidize water molecules into molecular oxygen. Each oxidation step removes one electron, and Kok et al. [6] proposed this as the explanation for the observed oscillation of the oxygen evolution pattern, shown by Joliot's experiments with saturating light flashes being used to power the photosynthetic process [46,47].

(a)

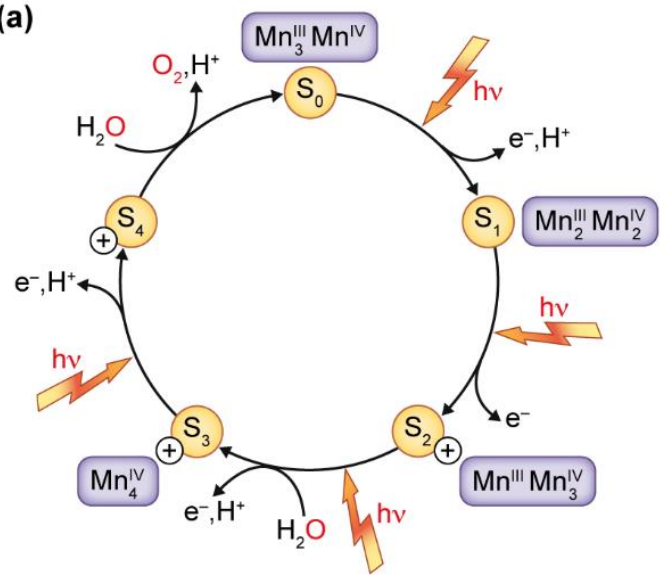

(b)

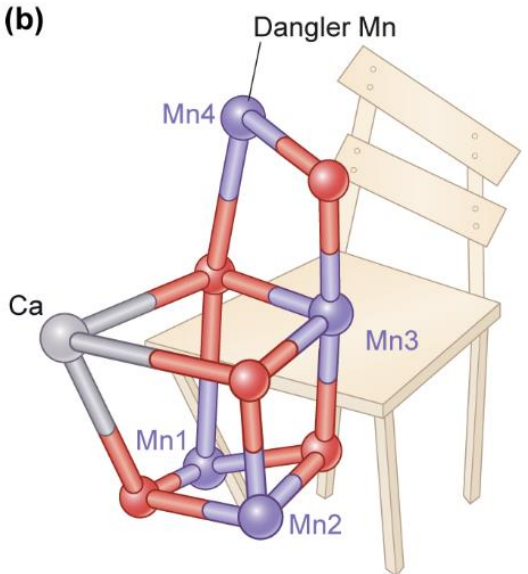

Figure 3. (a) The Kok cycle showing the steps of oxygen evolution in the oxygen evolving complex (OEC) of photosystem II (PSII) with details of the $S_{i}$ states $\left(S_{0}-S_{4}\right)$, the light induced oxidation steps of electron $\left(\mathrm{e}^{-}\right)$and proton $\left(\mathrm{H}^{+}\right)$release, together with the uptake of two molecules of $\mathrm{H}_{2} \mathrm{O}$, which can be summarized to: $2 \mathrm{H}_{2} \mathrm{O} \rightarrow 4 \mathrm{H}^{+}+4 \mathrm{e}^{-}+\mathrm{O}_{2}$. (b) The chemical structure shows the configuration and position of the metal atoms in the Mn4Ca cluster, resembling a distorted chair-like form. The distorted seat base is formed by three $\mathrm{Mn}$ and one Ca atoms in a cubane structure, and the back is formed by the fourth Mn (Mn4), the so-called dangler Mn, which lies outside the cubane, and has been proposed to act as the site of catalysis.

The structural and functional details of the intact $\mathrm{Mn}_{4} \mathrm{CaO}_{5}$ cluster were not revealed until 2001, where Zouni et al. [48] determined the three-dimensional structure of the OEC at $3.8 \AA$ resolution. Subsequently, Ferreira and co-workers suggested that the structure of the $\mathrm{OEC}$ is a $\mathrm{Mn}_{3} \mathrm{Ca}$ cubane structure [49], with the configuration of the metals inside the cluster resembling a distorted chair-like form (Figure 3b). The distorted seat base of the chair is formed by three $\mathrm{Mn}$, one $\mathrm{Ca}$, and four oxygen atoms, and the back of the chair is formed by the last Mn atom, the so-called dangler Mn, which lifts out the oxygen from its central position in the cluster (Figure 3b) [50]. This suggests that Mn4 has a more flexible location than the other metal atoms [51], and it might function as a gate for releasing protons from the $\mathrm{Mn}_{4} \mathrm{CaO}_{5}$ cluster [52,53]. In 2011, the oxo-bridges and exact distances among the individual metal atoms, along with the accurate orientation of the lateral amino acid binding residues, was revealed from the high-resolution structure of PSII at 1.9 A produced by Umena et al. [54]. Despite great progress in the understanding of OEC in PSII, several challenges remain. One pertinent question is the structure of the elusive $\mathrm{S} 4$ state, and the understanding of the mechanism of $\mathrm{O}-\mathrm{O}$ bond formation. Zhang and Sun [53] have proposed a novel mechanism where the dangler Mn4 acts as the site of catalysis, forming a $\mathrm{Mn}(\mathrm{VII})$-dioxo intermediate following charge rearrangement of the Mn cluster in the S4 state, triggering O-O bond formation and oxygen evolution. Experimental studies enabling a 
possible stabilization and characterization of the S4 state would finally complete our knowledge of the Kok cycle [55].

The light-induced process in PSII is very efficient, with a quantum yield of over $90 \%$. With a turnover time of OEC of only $\approx 2 \mathrm{~ms}$ and that of the whole PSII of $\approx 10 \mathrm{~ms}$, OEC performs more than $10^{5}$ reaction cycle before it must be replaced $[55,56]$. The $\mathrm{Mn}_{4} \mathrm{CaO}_{5}$ cluster is assembled by the stepwise binding of $\mathrm{Mn}^{2+}$ ions, as well as light-driven photooxidation of $\mathrm{Mn}^{2+}$ to $\mathrm{Mn}^{\geq 3+}$ to the co-factor depleted PSII (apo-OEC), as the Mn atoms become coordinated within the ligation matrix of the active site, a process called photoactivation [57,58]. The D1 carboxylate ligand, Asp170, plays a pivotal role during the assembly process by forming a high affinity site for Mn binding, involved in the initial photooxidation of $\mathrm{Mn}^{2+}$ [59]. However, the major question about the photoactivation mechanism is where the initial $\mathrm{Mn}^{2+}$ binding site is in the apo-OEC. Among the five metal sites (Mn1-Mn4 and Ca) of the $\mathrm{Mn}_{4} \mathrm{CaO}_{5}$ cluster it was recently concluded that the $\mathrm{Mn} 1$ site, likely in equilibrium with the $\mathrm{Mn} 2$ site, is the site of initial $\mathrm{Mn}^{2+}$ binding, which is supported by the $\mathrm{pH}$ dependence of the dissociation constant of $\mathrm{Mn}^{2+}$ and the effect of the chemical modification of His-residues in apo-OEC. This suggests the involvement of a His side chain in the high affinity site of $\mathrm{Mn}^{2+}$ binding. Whether the Mn ions are recycled during PSII repair remains unknown.

Mn deficiency alters the macro-organization of PSII, as demonstrated by a pronounced decrease in the abundance of PSII-LHCII supercomplexes under increasing Mn deficiency [60]. Furthermore, the abundance of D1 together with the PSII membrane extrinsic proteins PsbP and PsbQ (but not PsbO) is significantly reduced under Mn deficiency [61-63].

\section{Manganese-Dependent Superoxide Dismutase}

Reactive oxygen species (ROS) are inevitable toxic byproducts of basic plant metabolism. ROS are extremely reactive with and harmful to all biomolecules, causing DNA and RNA damage, protein oxidation and lipid peroxidation (collectively referred to as oxidative stress) [64]. Plant cells have developed an anti-oxidative defense system employing the ROS scavenging enzyme superoxide dismutase (SOD) functioning in cellular adaptation to oxidative stress. SODs are a family of metalloenzymes, which catalyze the dismutation of superoxide radicals into molecular oxygen $\left(\mathrm{O}_{2}\right)$ and hydrogen peroxide $\left(\mathrm{H}_{2} \mathrm{O}_{2}\right)$.

In plant cells, ROS are primarily formed in chloroplasts, mitochondria and peroxisomes, and it is therefore crucial that SODs are present in these compartments for ROS detoxification. Based on the prosthetic metal used by SOD, being $\mathrm{Cu}$, Fe, or $\mathrm{Mn}$, plant SODs are classified into three groups: Fe-SOD, $\mathrm{Mn}-\mathrm{SOD}$, and $\mathrm{Cu}-\mathrm{Zn}-\mathrm{SOD}$, which are localized to the chloroplast; mitochondria and peroxisomes; chloroplast and cytoplasm, respectively. While $\mathrm{Fe}$ and $\mathrm{Cu}$ are well-known for their reactivity with $\mathrm{H}_{2} \mathrm{O}_{2}$, which generates the highly reactive hydroxyl-radical via the so-called Fenton reaction, $\mathrm{Mn}$ is less prone to such chemistry owing to a greater reduction potential. The first Mn-SOD purified and biochemically characterized from a higher plant was the enzyme from pea leaves [65-67]. The regulation of Mn-SOD activity is far from trivial, as Mn deficiency has been reported to increase Mn-SOD activities in some studies but significantly inhibit the enzyme in others [68-70]. These contrasting findings are still under debate, but might be explained by differences in experimental setups and the plant species studied.

Plant Mn-SOD is typically found in mitochondria, but has also been detected in peroxisomes [71]. In higher plants, the molecular structure of Mn-SOD is homotetrameric, with a single Mn atom per subunit. The active site of Mn-SOD is highly conserved, and plant Mn-SODs share approximately $70 \%$ sequence similarity across a wide range of plant species [72,73]. In the resting state of $\mathrm{Mn}-\mathrm{SOD}$, $\mathrm{Mn}^{3+}$ is bound in a trigonal bipyramidal geometry (TBp, Figure 1) to the side chains of 3 His residues, one Asp residue, and one solvent ligand. The latter is thought to be a hydroxide ion when Mn-SOD is exerting the dismutase activity. This leaves an open coordination site on the metal, which allows the superoxide anion to bind to the $\mathrm{Mn}^{3+}$ center. The electron derived from superoxide oxidation is transferred to $\mathrm{Mn}^{3+}$, producing $\mathrm{Mn}^{2+}-\mathrm{SOD}$ and $\mathrm{O}_{2}[17,74]$. The Mn-SOD dismutation mechanism involves the alternation of Mn-SOD between the oxidised $\left(\mathrm{Mn}^{3+}\right)$ and less oxidised $\left(\mathrm{Mn}^{2+}\right)$ state of $\mathrm{Mn}$ 
in the course of dismutating superoxide radicals [73,74]. The metal-ligand interaction within the active site of Mn-SOD follows the thermodynamics predicted by the HSAB rule [21]. The hydroxide and Asp ligands are hard bases, whereas His is a borderline base. Consequently, it follows the trend that hard-borderline acids like $\mathrm{Mn}^{3+}$ and $\mathrm{Fe}^{3+}$ should coordinate with the active site. It has been observed that the geometry of the coordination is the same, when the active site of Mn-SOD is bound to $\mathrm{Fe}^{3+}$ or $\mathrm{Mn}^{3+}$ [75]. They both demonstrate a five-coordinate geometry. However, it has been shown that Mn-SOD is only active when coordinated with $\mathrm{Mn}^{3+}$. When $\mathrm{Mn}^{3+}$ is bound to Mn-SOD the specific activity is more than 30 times higher than observed with $\mathrm{Fe}^{3+}$ coordination. Furthermore, it has been found that the redox potential of $\mathrm{Fe}^{3+}$ substituted Mn-SOD is too high to allow catalytic turnover of superoxides. Although Mn-SOD potentially binds both $\mathrm{Mn}^{3+}$ and $\mathrm{Fe}^{3+}$, the Fe substitution into a Mn-SOD protein matrix generally yields inactive proteins [76]. However, among the Fe/Mn SODs a sub-class of cambialistic SODs exists. These SODs have the capacity to utilize either Fe or Mn in their active site dependent on metal availability [77]. In plants, cambialistic SODs showing the same activity when either Fe or Mn is present was first reported by Chen et al. [44]. This observation implies the possible presence of an adaptation mechanism enabling a fine-tuning of the functional activity in response to different availabilities of metal micronutrients. A greater understanding of SODs with cambialistic properties will allow development of plants tolerant to multiple stresses to help satisfy the global growing demand of feed and food [78].

The correct insertion of Mn into Mn-SOD of Arabidopsis is likely to involve the AtMTM1-encoded protein targeted to the mitochondria in plant cells. The protein is regulated by the superoxide anion availability providing evidence for its involvement in activation of Mn-SOD [79]. Changes in SOD encoding gene transcript levels and SOD activity are generally regarded as indicators of the level of ROS production and oxidative stress [80]. A study in the green algae Chlamydomonas under Mn-deficient conditions showed a loss of Mn-SOD activity before that of PSII efficiency, suggesting a regulated intraorganellar supply of Mn to support PSII function in preference to Mn-SOD function in the mitochondria [81]. Thus, prolonged Mn-deficiency in plants is characterized by leaf necrosis, at least partly owing to a decrease in Mn-SOD levels accompanied by an increase in free oxygen radicals $[8,81]$. Manganese-SOD activity increases from the base to the tip in leaves, indicating that ROS production increases in peroxisomes or in the respiratory chain in mitochondria in aging mesophyll cells in wheat [82]. Transgenic tobacco plants carrying a unique Mn-SOD isoform targeted to the chloroplasts were shown to have a 1.5-2-fold higher Mn-SOD activity than untransformed plants [83]. This overexpression of Mn-SOD provided increased protection from oxidative stress caused by ROS generating chemicals, but did not provide protection from ROS generated via photooxidation under photoinhibitory conditions, most likely due to the sub-organellar localization of the enzyme [83,84].

\section{Manganese-Dependent Oxalate Oxidase}

Oxalate oxidase $(\mathrm{OxOx})$ is a $\mathrm{Mn}$-dependent germin enzyme, which catalyzes the oxygen dependent degradation of oxalate by oxidation into two moles of $\mathrm{CO}_{2}$, in a reaction that is coupled with the formation of $\mathrm{H}_{2} \mathrm{O}_{2}$ [85]. The involvement of $\mathrm{Mn}$ is unique, as there is no evidence for the involvement of other metals in the oxalate detoxification process [86]. Most knowledge on OxOx in plants has derived from work in cereals [86-90]. The activity of OxOx is localized to the apoplast and exerts a dual role in the defense of pathogens by destroying fungal toxins, and promoting lignification through the generation of $\mathrm{H}_{2} \mathrm{O}_{2}$ necessary for cross-linking reactions [91]. Oxalate oxidase is furthermore likely to have a role in seed maturation and germination, where isoforms of germin have been reported as discrete markers, however, the physiological relevance of the induction of OxOx activity during plant development is unclear [87].

Crystallographic assessment of OxOx from barley has revealed that $\mathrm{Mn}$ is bound by the side chains of a 3 His cluster and 1 Glu residue, as well as two adjacent water molecules in an octahedral (Oh, Figure 1a) metal complex [92]. The binding ligands are somewhat similar to those of Mn-SOD, with only Glu substituted with Asp (Figure 1b). The active site of OxOx is situated in the core of 
the complex composed of two nearly structurally equivalent $\beta$-barrel domains of the monomer, each containing a $\mathrm{Mn}$ ion. The active form of $\mathrm{OxOx}$ is a hexamer, organized as a trimer of dimers, in which each monomer has a canonical cupin fold $[92,93]$. Spectroscopic characterization has shown that the OxOx with the reduced $\mathrm{Mn}$ (II) form at the active center lacks activity, but the activity is restored when the metal center is oxidized to either $\mathrm{Mn}$ (III) or Mn(IV) forms. The proposed mechanism regulating the redox state of the metal center has been described by Whittaker et al. (2007) and involves the binding of oxalate as a monoanion directly to Mn center where an electron is transferred from the oxalate ligand to $\mathrm{Mn}$ (III). During the resulting reduction of $\mathrm{Mn}$ (III) to $\mathrm{Mn}$ (II) a highly unstable oxalyl free radical is formed, which undergoes spontaneous degradation to $\mathrm{CO}_{2}$ and a carbon dioxide radical anion $\left(\mathrm{CO}_{2}{ }^{-}\right)$, which binds to the positive charge of $\mathrm{Mn}(\mathrm{II})$. In solution, $\mathrm{CO}_{2}^{-}$undergoes rapid electron transfer to dioxygen, yielding the protonated form of superoxide (the hydroperoxyl radical, $\mathrm{HO}_{2}{ }^{*}$ ) and an additional $\mathrm{CO}_{2}$. Hydroperoxyl exhibits a pKa of 4.8, meaning that this anionic form of the radical is by far the predominant species at physiological $\mathrm{pH}$. Finally, the subsequent re-oxidation of $\mathrm{Mn}$ (II) to regain catalytic activity of $\mathrm{OxOx}$ occurs by electron transfer oxidation of $\mathrm{Mn}$ (II) by the hydroperoxyl radical to generate a molecule of $\mathrm{H}_{2} \mathrm{O}_{2}$.

Several pathogens are believed to make use of oxalate in pathogenesis, including Sclerotinia sclerotiorum (white mold) and Erysiphaceae (powdery mildew). The OxOx enzyme activity has been detected in young barley roots and in the leaves of mature plants in response to powdery mildew infection $[94,95]$. The response of the enzymes was detected already from $24 \mathrm{~h}$ after pathogen attack induced by inoculation [95]. The severity of take-all disease in wheat is related to the seed Mn content, with plants from seed with the largest Mn content yielding $165 \mathrm{~kg} / \mathrm{ha}$ more under severe disease conditions [96]. Given the requirement for $\mathrm{Mn}$ in $\mathrm{OxOx}$, it is possible that resistance towards the disease is associated with $\mathrm{OxOx}$ activity, since the $\mathrm{H}_{2} \mathrm{O}_{2}$ produced by OxOx could be used in lignin cross-linking as described above. In support, two germin-like protein were identified in a GWAS mapping analysis of 248 barley varieties screening for candidate genes conferring tolerance to $\mathrm{Mn}$ deficiency [97].

As a means of protecting plants against the fungal toxin, the strategy of introducing oxalate degrading enzymes into plants, has been evaluated. When the OxOx gene from barley was introduced into oilseed rape it conferred resistance to exogenously supplied oxalic acid, as a result of increased levels of OxOx and enzyme activity [98]. In another study, transgenic oilseed rape constitutively expressing wheat OxOx showed increased OxOx enzyme activity and enhanced resistance towards S. sclerotiorum with up to $90 \%$ disease reduction compared to untransformed plants [99].

\section{Conclusions}

In this review we have used the EC classification of enzymes and the cofactor information contained in the UniProt Knowledgebase to provide an overview of the biochemical roles provided by $\mathrm{Mn}$ as an essential catalytic metal cofactor in plant enzymes. The distribution of $\mathrm{Mn}$ across all enzyme classes and its involvement in a large variety of enzymes is reflected by its multi-facetted chemistry, including redox state cycling, as well as an intriguing use of compartmentalization and chaperones to avoid mismetallation within plant cells. Knowledge on the role of $\mathrm{Mn}$ in biochemistry is accumulating, but the role of $\mathrm{Mn}$ in metalloenzyme activation and, not least, the resulting impact on metabolism is still in its infancy. A much better understanding of how metal homeostasis in the cell is regulated and how chaperones and metal sensors discriminate between elements is necessary to allow further understanding of the role of metals in the biochemistry of plants.

Author Contributions: The authors contributed equally to this work.

Funding: This research was funded by the Independent Research Fund Denmark-Technology and Production Sciences [Grant No. DFF-5054-00042 to S.B.S.].

Conflicts of Interest: The authors declare that there is no conflict of interest. 


\section{References}

1. Saussure, T.D. Recherches Chimiques sur la Végétation; Nyon: Paris, France, 1804.

2. McHargue, J.S. The effect of manganese on the growth of wheat: A source of manganese for agricultural purposes. J. Ind. Eng. Chem. 1919, 11, 332-335. [CrossRef]

3. Loew, O.; Sawa, S. On the action of manganese compounds on plants. Bull. Coll. Agric. Tokyo 1902, 5, 161-172.

4. Pirson, A. Ernährungs- und stoffwechselphysiologische Untersuchungen an Fontinalis und Chlorella. Zeitschrift für Botanik 1937, 31, 193-267.

5. Pirson, A.; Tichy, C.; Wilhelmi, G. Stoffwechsel und mineralsalzernährung Einzelliger Grünalgen. Planta 1951, 40, 199-253. [CrossRef]

6. Kok, B.; Forbush, B.; Mcgloin, M. Cooperation of charges in photosynthetic oxygen evolution-I. A linear four step mechanism. Photochem. Photobiol. 1970, 11, 457-475. [CrossRef] [PubMed]

7. Spector, M.; Winget, G.D. Purification of a manganese-containing protein involved in photosynthetic oxygen evolution and its use in reconstituting an active membrane. Proc. Natl. Acad. Sci. USA 1980, 77, 957-959. [CrossRef] [PubMed]

8. Schmidt, S.B.; Jensen, P.E.; Husted, S. Manganese deficiency in plants: The impact on Photosystem II. Trends Plant Sci. 2016, 21, 622-632. [CrossRef]

9. Hebbern, C.A.; Pedas, P.; Schjoerring, J.K.; Knudsen, L.; Husted, S. Genotypic differences in manganese efficiency: Field experiments with winter barley (Hordeum vulgare L.). Plant Soil 2005, 272, 233-244. [CrossRef]

10. Schmidt, S.B.; Pedas, P.; Laursen, K.H.; Schjoerring, J.K.; Husted, S. Latent manganese deficiency in barley can be diagnosed and remediated on the basis of chlorophyll $a$ fluorescence measurements. Plant Soil 2013, 372, 417-429. [CrossRef]

11. Stoltz, E.; Wallenhammar, A.-C. Manganese application increases winter hardiness in barley. Field Crops Res. 2014, 164, 148-153. [CrossRef]

12. Jiang, W.Z. Mn use efficiency in different wheat cultivars. Environ. Exp. Bot. 2006, 57, 41-50. [CrossRef]

13. George, T.S.; French, A.S.; Brown, L.K.; Karley, A.J.; White, P.J.; Ramsay, L.; Daniell, T.J. Genotypic variation in the ability of landraces and commercial cereal varieties to avoid manganese deficiency in soils with limited manganese availability: Is there a role for root-exuded phytases? Physiol. Plant. 2014, 151, 243-256. [CrossRef] [PubMed]

14. Pallotta, A.M.; Graham, D.R.; Langridge, P.; Sparrow, B.D.H.; Barker, J.S. RFLP mapping of manganese efficiency in barley. Theor. Appl. Genet. 2000, 101, 1100-1108. [CrossRef]

15. Yang, X.E.; Chen, W.R.; Feng, Y. Improving human micronutrient nutrition through biofortification in the soil-plant system: China as a case study. Environ. Geochem. Health 2007, 29, 413-428. [CrossRef] [PubMed]

16. Waldron, K.J.; Rutherford, J.C.; Ford, D.; Robinson, N.J. Metalloproteins and metal sensing. Nature 2009, 460, 823-830. [CrossRef] [PubMed]

17. Zhu, W.; Richards, N.G.J. Biological functions controlled by manganese redox changes in mononuclear Mn-dependent enzymes. Essays Biochem. 2017, 61, 259-270. [CrossRef] [PubMed]

18. Iranzo, O. Manganese complexes displaying superoxide dismutase activity: A balance between different factors. Bioorg. Chem. 2011, 39, 73-87. [CrossRef] [PubMed]

19. Saito, M.A.; Sigman, D.M.; Morel, F.M.M. The bioinorganic chemistry of the ancient ocean: The co-evolution of cyanobacterial metal requirements and biogeochemical cycles at the Archean-Proterozoic boundary? Inorg. Chim. Acta 2003, 356, 308-318. [CrossRef]

20. Irving, H.; Williams, R.J.P. Order of Stability of Metal Complexes. Nature 1948, 162, 746-747. [CrossRef]

21. Pearson, R.G. Absolute electronegativity and hardness: Application to inorganic chemistry. Inorg. Chem. 1988, 27, 734-740. [CrossRef]

22. Retnoningrum, D.S.; Yoshida, H.; Arumsari, S.; Kamitori, S.; Ismaya, W.T. The first crystal structure of manganese superoxide dismutase from the genus Staphylococcus. Acta Crystallogr. Sect. F Struct. Biol. Commun. 2018, 74, 135-142. [CrossRef]

23. Irving, H.; Williams, R.J.P. 637. The stability of transition-metal complexes. J. Chem. Soc. 1953. [CrossRef]

24. Andreini, C.; Bertini, I.; Cavallaro, G.; Holliday, G.L.; Thornton, J.M. Metal ions in biological catalysis: From enzyme databases to general principles. JBIC 2008, 13, 1205-1218. [CrossRef]

25. Christianson, D.W. Structural chemistry and biology of manganese metalloenzymes. Prog. Biophys. Mol. Biol. 1997, 67. [CrossRef] 
26. Glusker, J.P. Structural aspects of metal liganding to functional groups in proteins. Adv. Protein Chem. 1991, 42, 1-76. [PubMed]

27. Khrustalev, V.V.; Barkovsky, E.V.; Khrustaleva, T.A. Magnesium and manganese binding sites on proteins have the same predominant motif of secondary structure. J. Theor. Biol. 2016, 395, 174-185. [CrossRef] [PubMed]

28. Auffinger, P.; Grover, N.; Westhof, E. Metal ion binding to RNA. Met. Ions Life Sci. 2011, 9, 1-35.

29. Bock, C.W.; Katz, A.K.; Markham, G.D.; Glusker, J.P. Manganese as a Replacement for Magnesium and Zinc: Functional Comparison of the Divalent Ions. J. Am. Chem. Soc. 1999, 121, 7360-7372. [CrossRef]

30. Williams, L.E.; Pittman, J.K. Dissecting pathways involved in manganese homeostasis and stress in higher plant cells. In Cell Biology of Metals and Nutrients; Hell, R., Mendel, R.-R., Eds.; Springer: Berlin/Heidelberg, Germany, 2010; pp. 95-117.

31. Hermans, C.; Conn, S.J.; Chen, J.; Xiao, Q.; Verbruggen, N. An update on magnesium homeostasis mechanisms in plants. Metallomics 2013, 5, 1170-1183. [CrossRef] [PubMed]

32. Dudev, T.; Lim, C. Competition among Metal Ions for Protein Binding Sites: Determinants of Metal Ion Selectivity in Proteins. Chem. Rev. 2014, 114, 538-556. [CrossRef]

33. Bloom, A.J. Metal regulation of metabolism. Curr. Opin. Chem. Biol. 2019, 49, 33-38. [CrossRef] [PubMed]

34. Lilley, R.M.; Wang, X.; Krausz, E.; Andrews, T.J. Complete Spectra of the Far-red Chemiluminescence of the Oxygenase Reaction of $\mathrm{Mn}^{2+}$-activated Ribulose-bisphosphate Carboxylase/Oxygenase Establish Excited $\mathrm{Mn}^{2+}$ as the Source. J. Biol. Chem. 2003, 278, 16488-16493. [CrossRef] [PubMed]

35. Bloom, A.J.; Kameritsch, P. Relative association of Rubisco with manganese and magnesium as a regulatory mechanism in plants. Physiol. Plant. 2017, 161, 545-559. [CrossRef] [PubMed]

36. Socha, A.L.; Guerinot, M.L. Mn-euvering manganese: The role of transporter gene family members in manganese uptake and mobilization in plants. Front. Plant Sci. 2014, 5, 1-16. [CrossRef] [PubMed]

37. Stengel, A.; Gugel, I.L.; Hilger, D.; Rengstl, B.; Jung, H.; Nickelsen, J. Initial steps of photosystem II de novo assembly and preloading with manganese take place in biogenesis centers in Synechocystis. Plant Cell 2012, 24, 660-675. [CrossRef] [PubMed]

38. Mizuno, K.; Whittaker, M.M.; Bachinger, H.P.; Whittaker, J.W. Calorimetric studies on the tight binding metal interactions of Escherichia coli manganese superoxide dismutase. J. Biol. Chem. 2004, 279, 27339-27344. [CrossRef]

39. Bondarava, N.; Beyer, P.; Krieger-Liszkay, A. Function of the $23 \mathrm{kDa}$ extrinsic protein of photosystem II as a manganese binding protein and its role in photoactivation. Biochim. Biophys. Acta 2005, 1708, 63-70. [CrossRef]

40. Bondarava, N.; Un, S.; Krieger-Liszkay, A. Manganese binding to the $23 \mathrm{kDa}$ extrinsic protein of photosystem II. Biochim. Biophys. Acta 2007, 1767, 583-588. [CrossRef]

41. Cao, P.; Xie, Y.; Li, M.; Pan, X.; Zhang, H.; Zhao, X.; Su, X.; Cheng, T.; Chang, W. Crystal structure analysis of extrinsic PsbP protein of photosystem II reveals a manganese-induced conformational change. Mol. Plant 2015, 8, 664-666. [CrossRef]

42. Ido, K.; Kakiuchi, S.; Uno, C.; Nishimura, T.; Fukao, Y.; Noguchi, T.; Sato, F.; Ifuku, K. The conserved His-144 in the PsbP protein is important for the interaction between the PsbP N-terminus and the Cyt b559 subunit of photosystem II. J. Biol. Chem. 2012, 287, 26377-26387. [CrossRef]

43. Emerson, J.P.; Kovaleva, E.G.; Farquhar, E.R.; Lipscomb, J.D.; Que, L. Swapping metals in Fe- and Mn-dependent dioxygenases: Evidence for oxygen activation without a change in metal redox state. Proc. Natl. Acad. Sci. USA 2008, 105, 7347-7352. [CrossRef]

44. Chen, H.-Y.; Hu, R.-G.; Wang, B.-Z.; Chen, W.-F.; Liu, W.-Y.; Schröder, W.; Frank, P.; Ulbrich, N. Structural studies of an eukaryotic cambialistic superoxide dismutase purified from the mature seeds of camphor tree. Arch. Biochem. Biophys. 2002, 404, 218-226. [CrossRef]

45. Tottey, S.; Waldron, K.J.; Firbank, S.J.; Reale, B.; Bessant, C.; Sato, K.; Cheek, T.R.; Gray, J.; Banfield, M.J.; Dennison, C.; et al. Protein-folding location can regulate manganese-binding versus copper- or zinc-binding. Nature 2008, 455, 1138-1142. [CrossRef] [PubMed]

46. Joliot, P. Kinetic studies of photosystem II in photosynthesis. Photochem. Photobiol. 1968, 8, 451-463. [CrossRef]

47. Joliot, P.; Barbieri, G.; Chabaud, R. Un Nouveau modele des centres photochimiques du systeme II. Photochem. Photobiol. 1969, 10, 309-329. [CrossRef] 
48. Zouni, A.; Witt, H.-T.; Kern, J.; Fromme, P.; Krauss, N.; Saenger, W.; Orth, P. Crystal structure of photosystem II from Synechococcus elongatus at 3.8 A resolution. Nature 2001, 409, 739-743. [CrossRef] [PubMed]

49. Ferreira, K.N.; Iverson, T.M.; Maghlaoui, K.; Barber, J.; Iwata, S. Architecture of the Photosynthetic Oxygen-Evolving Center. Science 2004, 303, 1831-1838. [CrossRef]

50. Kawakami, K.; Umena, Y.; Kamiya, N.; Shen, J.-R. Structure of the catalytic, inorganic core of oxygen-evolving photosystem II at 1.9 angstrom resolution. J. Photochem. Photobiol. B Biol. 2011, 104, 9-18. [CrossRef]

51. Cao, P.; Su, X.; Pan, X.; Liu, Z.; Chang, W.; Li, M. Structure, assembly and energy transfer of plant photosystem II supercomplex. BBA Bioenergy 2018, 1859, 633-644. [CrossRef]

52. Reiss, K.; Morzan, U.N.; Grigas, A.T.; Batista, V.S. Water Network Dynamics Next to the Oxygen-Evolving Complex of Photosystem II. Inorganics 2019, 7, 39. [CrossRef]

53. Zhang, B.; Sun, L. Why nature chose the $\mathrm{Mn}_{4} \mathrm{CaO}_{5}$ cluster as water-splitting catalyst in photosystem II: A new hypothesis for the mechanism of O-O bond formation. Dalton Trans. 2018, 47, 14381-14387. [CrossRef] [PubMed]

54. Umena, Y.; Kawakami, K.; Shen, J.-R.; Kamiya, N. Crystal structure of oxygen-evolving photosystem II at a resolution of 1.9 angstrom. Nature 2011, 473, U55-U65. [CrossRef] [PubMed]

55. Lubitz, W.; Chrysina, M.; Cox, N. Water oxidation in photosystem II. Photosynth. Res. 2019. [CrossRef] [PubMed]

56. Vinyard, D.J.; Brudvig, G.W. Progress Toward a Molecular Mechanism of Water Oxidation in Photosystem II. Annu. Rev. Phys. Chem. 2017, 68, 101-116. [CrossRef] [PubMed]

57. Dasgupta, J.; Ananyev, G.M.; Dismukes, G.C. Photoassembly of the water-oxidizing complex in photosystem II. Coord. Chem. Rev. 2008, 252, 347-360. [CrossRef] [PubMed]

58. Burnap, R.L. D1 protein processing and Mn cluster assembly in light of the emerging Photosystem II structure. PCCP 2004, 6, 4803-4809. [CrossRef]

59. Nixon, P.J.; Diner, B.A. Aspartate 170 of the photosystem II reaction center polypeptide D1 is involved in the assembly of the oxygen-evolving manganese cluster. Biochemistry 1992, 31, 942-948. [CrossRef]

60. Schmidt, S.B.; Persson, D.P.; Powikrowska, M.; Frydenvang, J.; Schjoerring, J.K.; Jensen, P.E.; Husted, S. Metal binding in photosystem II super- and subcomplexes from barley thylakoids. Plant Physiol. 2015, 168, 1490-1502. [CrossRef]

61. De Bang, T.C.; Petersen, J.; Pedas, P.R.; Rogowska-Wrzesinska, A.; Jensen, O.N.; Schjoerring, J.K.; Jensen, P.E.; Thelen, J.J.; Husted, S. A laser ablation ICP-MS based method for multiplexed immunoblot analysis: Applications to manganese-dependent protein dynamics of photosystem II in barley (Hordeum vulgare L.). Plant J. 2015, 83, 555-565. [CrossRef]

62. Schmidt, S.B.; Powikrowska, M.; Krogholm, K.S.; Naumann-Busch, B.; Schjoerring, J.K.; Husted, S.; Jensen, P.E.; Pedas, P.R. Photosystem II functionality in barley responds dynamically to changes in leaf manganese status. Front. Plant Sci. 2016, 7, 1-12. [CrossRef]

63. Husted, S.; Laursen, K.H.; Hebbern, C.A.; Schmidt, S.B.; Pedas, P.; Haldrup, A.; Jensen, P.E. Manganese deficiency leads to genotype-specific changes in fluorescence induction kinetics and state transitions. Plant Physiol. 2009, 150, 825-833. [CrossRef] [PubMed]

64. Mittler, R. ROS Are Good. Trends Plant Sci. 2017, 22, 11-19. [CrossRef] [PubMed]

65. Sevilla, F.; López-Gorgé, J.; Gómez, M.; del Río, L.A. Manganese superoxide dismutase from a higher plant. Planta 1980, 150, 153-157. [CrossRef] [PubMed]

66. Sevilla, F.; López-Gorgé, J.; del Río, L.A. Characterization of a Manganese Superoxide Dismutase from the Higher Plant Pisum sativum. Plant Physiol. 1982, 70, 1321-1326. [CrossRef] [PubMed]

67. Fernandez, V.M.; Sevilla, F.; López-Gorgé, J.; del Río, L.A. Evidence for manganese(III) binding to the mangano superoxide dismutase from a higher plant (Pisum sativum L.). J. Inorg. Biochem. 1982, 16, $79-84$. [CrossRef]

68. Yu, Q.; Rengel, Z. Micronutrient deficiency influences plant growth and activities of superoxide dismutases in narrow-leafed lupins. Ann. Bot. 1999, 83, 175-182. [CrossRef]

69. Tewari, R.K.; Kumar, P.; Sharma, P.N. Oxidative stress and antioxidant responses of mulberry (Morus alba) plants subjected to deficiency and excess of manganese. Acta Physiol. Plant. 2013, 35, 3345-3356. [CrossRef]

70. Del Río, L.A.; Sevilla, F.; Gómez, M.; Yañez, J.; López, J. Superoxide dismutase: An enzyme system for the study of micronutrient interactions in plants. Planta 1978, 140, 221-225. [CrossRef] 
71. Del Río, L.A.; Lyon, D.S.; Olah, I.; Glick, B.; Salin, M.L. Immunocytochemical evidence for a peroxisomal localization of manganese superoxide dismutase in leaf protoplasts from a higher plant. Planta 1983, 158, 216-224. [CrossRef]

72. Bowler, C.; Vancamp, W.; Vanmontagu, M.; Inze, D. Superoxide-dismutase in plants. Crit. Rev. Plant Sci. 1994, 13, 199-218. [CrossRef]

73. Miller, A.-F. Superoxide dismutases: Ancient enzymes and new insights. FEBS Lett. 2012, 586, 585-595. [CrossRef] [PubMed]

74. Abreu, I.A.; Cabelli, D.E. Superoxide dismutases-a review of the metal-associated mechanistic variations. Biochim. Biophys. Acta 2010, 1804, 263-274. [CrossRef] [PubMed]

75. Jackson, T.A.; Gutman, C.T.; Maliekal, J.; Miller, A.F.; Brunold, T.C. Geometric and electronic structures of manganese-substituted iron superoxide dismutase. Inorg. Chem. 2013, 52, 3356-3367. [CrossRef] [PubMed]

76. Beyer, W.F., Jr.; Fridovich, I. In vivo competition between iron and manganese for occupancy of the active site region of the manganese-superoxide dismutase of Escherichia coli. J. Biol. Chem. 1991, 266, 303-308. [PubMed]

77. Krauss, I.R.; Merlino, A.; Pica, A.; Rullo, R.; Bertoni, A.; Capasso, A.; Amato, M.; Riccitiello, F.; De Vendittis, E.; Sica, F. Fine tuning of metal-specific activity in the Mn-like group of cambialistic superoxide dismutases. RSC Adv. 2015, 5, 87876-87887. [CrossRef]

78. Mishra, P.; Sharma, P. Superoxide Dismutases (SODs) and Their Role in Regulating Abiotic Stress induced Oxidative Stress in Plants. In Reactive Oxygen, Nitrogen and Sulfur Species in Plants; Hasanuzzaman, V.F.M., Nahar, K., Fujita, M., Eds.; Wiley: Hoboken, NJ, USA, 2019; pp. 53-88.

79. Su, Z.; Chai, M.-F.; Lu, P.-L.; An, R.; Chen, J.; Wang, X.-C. AtMTM1, a novel mitochondrial protein, may be involved in activation of the manganese-containing superoxide dismutase in Arabidopsis. Planta 2007, 226, 1031-1039. [CrossRef] [PubMed]

80. Foyer, C.H.; Noctor, G. Redox Regulation in Photosynthetic Organisms: Signaling, Acclimation, and Practical Implications. Antioxid. Redox Signal. 2009, 11, 861-905. [CrossRef] [PubMed]

81. Allen, M.D.; Kropat, J.; Tottey, S.; Del Campo, J.A.; Merchant, S.S. Manganese deficiency in Chlamydomonas results in loss of photosystem II and MnSOD function, sensitivity to peroxides, and secondary phosphorus and iron deficiency. Plant Physiol. 2007, 143, 263-277. [CrossRef]

82. Leonowicz, G.; Trzebuniak, K.F.; Zimak-Piekarczyk, P.; Ślesak, I.; Mysliwa-Kurdziel, B. The activity of superoxide dismutases (SODs) at the early stages of wheat deetiolation. PLoS ONE 2018, 13, e0194678. [CrossRef]

83. Bowler, C.; Slooten, L.; Vandenbranden, S.; De Rycke, R.; Botterman, J.; Sybesma, C.; Van Montagu, M.; Inze, D. Manganese superoxide dismutase can reduce cellular damage mediated by oxygen radicals in transgenic plants. EMBO J. 1991, 10, 1723-1732. [CrossRef]

84. Allen, R.D. Dissection of Oxidative Stress Tolerance Using Transgenic Plants. Plant Physiol. 1995, 107, 1049-1054. [CrossRef] [PubMed]

85. Whittaker, M.M.; Whittaker, J.W. Characterization of recombinant barley oxalate oxidase expressed by Pichia pastoris. J. Biol. Inorg. Chem. 2002, 7, 136-145. [CrossRef] [PubMed]

86. Requena, L.; Bornemann, S. Barley (Hordeum vulgare) oxalate oxidase is a manganese-containing enzyme. Biochem. J. 1999, 343, 185-190. [CrossRef] [PubMed]

87. Caliskan, M.; Cuming, A.C. Spatial specificity of $\mathrm{H}_{2} \mathrm{O}_{2}$-generating oxalate oxidase gene expression during wheat embryo germination. Plant J. 1998, 15, 165-171. [CrossRef] [PubMed]

88. Kotsira, V.P.; Clonis, Y.D. Oxalate oxidase from barley roots: Purification to homogeneity and study of some molecular, catalytic, and binding properties. Arch. Biochem. Biophys. 1997, 340, 239-249. [CrossRef] [PubMed]

89. Li, X.C.; Liao, Y.Y.; Leung, D.W.M.; Wang, H.Y.; Chen, B.L.; Peng, X.X.; Liu, E.E. Divergent biochemical and enzymatic properties of oxalate oxidase isoforms encoded by four similar genes in rice. Phytochemistry 2015, 118, 216-223. [CrossRef] [PubMed]

90. Vuletic, M.; Sukalovic, V.H. Characterization of cell wall oxalate oxidase from maize roots. Plant Sci. 2000, 157, 257-263. [CrossRef]

91. Darvill, J.E.; McNeil, M.; Darvill, A.G.; Albersheim, P. Structure of Plant Cell Walls: XI. Glucuronoarabinoxylan, a second hemicellulose in the primary cell walls of suspension-cultured sycamore cells. Plant Physiol. 1980, 66, 1135-1139. [CrossRef] 
92. Woo, E.J.; Dunwell, J.M.; Goodenough, P.W.; Marvier, A.C.; Pickersgill, R.W. Germin is a manganese containing homohexamer with oxalate oxidase and superoxide dismutase activities. Nat. Struct. Biol. 2000, 7, 1036-1040. [CrossRef]

93. Woo, E.J.; Dunwell, J.M.; Goodenough, P.W.; Pickersgill, R.W. Barley oxalate oxidase is a hexameric protein related to seed storage proteins: Evidence from X-ray crystallography. FEBS Lett. 1998, 437, 87-90. [CrossRef]

94. Dumas, B.; Freyssinet, G.; Pallett, K.E. Tissue-Specific Expression of Germin-Like Oxalate Oxidase during Development and Fungal Infection of Barley Seedlings. Plant Physiol. 1995, 107, 1091-1096. [CrossRef] [PubMed]

95. Zhang, Z.; Collinge, D.B.; Thordal-Christensen, H. Germin-like oxalate oxidase, a $\mathrm{H}_{2} \mathrm{O}_{2}$-producing enzyme, accumulates in barley attacked by the powdery mildew fungus. Plant J. 1995, 8, 139-145. [CrossRef]

96. McCay-Buis, T.S.; Huber, D.M.; Graham, R.D.; Phillips, J.D.; Miskin, K.E. Manganese seed content and take-all of cereals. J. Plant Nutr. 1995, 18, 1711-1721. [CrossRef]

97. Leplat, F.; Pedas, P.R.; Rasmussen, S.K.; Husted, S. Identification of manganese efficiency candidate genes in winter barley (Hordeum vulgare) using genome wide association mapping. BMC Genom. 2016, 17, 775. [CrossRef]

98. Thompson, C.; Dunwell, J.M.; Johnstone, C.E.; Lay, V.; Ray, J.; Schmitt, M.; Watson, H.; Nisbet, G. Degradation of oxalic acid by transgenic oilseed rape plants expressing oxalate oxidase. Euphytica 1995, 85, 169-172. [CrossRef]

99. Dong, X.; Ji, R.; Guo, X.; Foster, S.J.; Chen, H.; Dong, C.; Liu, Y.; Hu, Q.; Liu, S. Expressing a gene encoding wheat oxalate oxidase enhances resistance to Sclerotinia sclerotiorum in oilseed rape (Brassica napus). Planta 2008, 228, 331. [CrossRef] [PubMed]

(C) 2019 by the authors. Licensee MDPI, Basel, Switzerland. This article is an open access article distributed under the terms and conditions of the Creative Commons Attribution (CC BY) license (http://creativecommons.org/licenses/by/4.0/). 